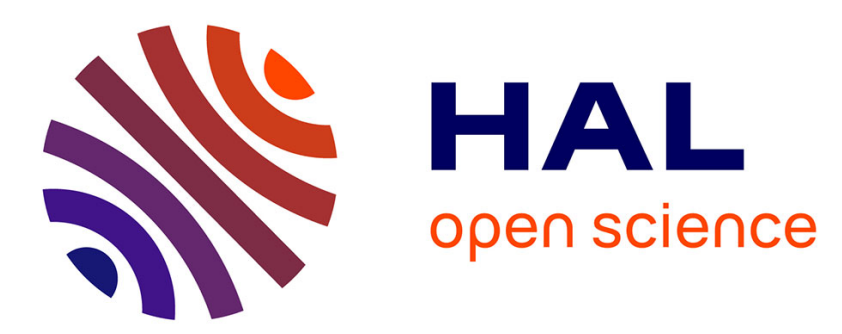

\title{
Study of the antimicrobial and antifouling properties of different oxide surfaces
}

\author{
W. Blel, L. Limousy, P. Dutournié, A. Ponche, A. Boucher, M. Le Fellic
}

\section{To cite this version:}

W. Blel, L. Limousy, P. Dutournié, A. Ponche, A. Boucher, et al.. Study of the antimicrobial and antifouling properties of different oxide surfaces. Environmental Science and Pollution Research, 2017, 24 (11), pp.9847-9858. 10.1007/s11356-016-7762-2 . hal-01924248

\section{HAL Id: hal-01924248 \\ https://hal.science/hal-01924248}

Submitted on 25 Oct 2019

HAL is a multi-disciplinary open access archive for the deposit and dissemination of scientific research documents, whether they are published or not. The documents may come from teaching and research institutions in France or abroad, or from public or private research centers.
L'archive ouverte pluridisciplinaire HAL, est destinée au dépôt et à la diffusion de documents scientifiques de niveau recherche, publiés ou non, émanant des établissements d'enseignement et de recherche français ou étrangers, des laboratoires publics ou privés. 
archives-ouvertes

\title{
Study of the antimicrobial and antifouling properties of different oxide surfaces
}

\author{
W. Blel, L. Limousy, P. Dutournié, A. Ponche, A. Boucher, M. Le Fellic
}

\section{To cite this version:}

W. Blel, L. Limousy, P. Dutournié, A. Ponche, A. Boucher, et al.. Study of the antimicrobial and antifouling properties of different oxide surfaces. Environmental Science and Pollution Research, Springer Verlag, 2017, 24 (11), pp.9847 - 9858. 10.1007/s11356-016-7762-2 . hal-01924248

\section{HAL Id: hal-01924248 \\ https: / hal.archives-ouvertes.fr/hal-01924248}

Submitted on 25 Oct 2019

HAL is a multi-disciplinary open access archive for the deposit and dissemination of scientific research documents, whether they are published or not. The documents may come from teaching and research institutions in France or abroad, or from public or private research centers.
L'archive ouverte pluridisciplinaire HAL, est destinée au dépôt et à la diffusion de documents scientifiques de niveau recherche, publiés ou non, émanant des établissements d'enseignement et de recherche français ou étrangers, des laboratoires publics ou privés. 


\title{
Study of the antimicrobial and antifouling properties of different oxide surfaces
}

\author{
W. Blel ${ }^{1} \cdot$ L. Limousy ${ }^{2} \cdot$ P. Dutournié ${ }^{2} \cdot$ A. Ponche $^{2} \cdot$ A. Boucher $^{3} \cdot$ M. Le Fellic $^{3}$
}

Received: 1 May 2016 / Accepted: 21 September 2016

\begin{abstract}
Membrane separation processes find applications in an array of fields as they use far less energy and chemical agents than competing processes. However, a major drawback of membrane technology is that biofilm formation alters membrane performances. Preventing biofilm formation is thus a pivotal challenge for larger-scale development of membrane processes. Here, we studied the comparative antibacterial activities of different inorganic membranes (ceramic and zeolitecoated ceramic with or without copper exchange) using several bacterial strains (Escherichia coli, Staphylococcus aureus, and Bacillus subtilis). In static conditions, alumina plates coated with $\mathrm{Cu}$-exchanged zeolite showed significant bactericidal activity. In dynamic mode (circulation of a
\end{abstract}

Highlights

Antibacterial activity was studied on $\mathrm{Cu}$-mordenite and Na-mordenite layers.

Bacterial adhesion was weak on the $\mathrm{Cu}$-mordenite membrane.

The Cu-mordenite layer remains antibacterial even at high bacterial concentrations.

The presence of copper induces an increase in membrane surface hydrophilicity.

The $\mathrm{Cu}$-mordenite layer remains functionalized after the filtration step.

Responsible editor: Philippe Garrigues

W. Blel

walid.blel@univ-nantes.fr

1 Laboratoire de Génie des procédés - environnement - agro-alimentaire (GEPEA), UMR CNRS 6144, Université de Nantes, Saint Nazaire, France

2 Institut de Science des Matériaux de Mulhouse (IS2M) UMR CNRS 7361, Université de Strasbourg, Université de Haute Alsace, Mulhouse, France

3 Laboratoire d'Ingénierie des MATériaux de Bretagne (LIMATB-EA 4250), Université de Bretagne Sud, Lorient, France contaminated nutrient medium), there was no observable bacterial adhesion at the surface of the $\mathrm{Cu}$-exchanged material. These results confirm the antifouling properties of the $\mathrm{Cu}$ mordenite layer due to both the increased hydrophilicity and antibacterial properties of the active layer.

Tests performed with tubular filtration membranes (without copper exchange) showed a significant decline in membrane hydraulic properties during filtration of culture media containing bacteria, whereas copper-exchanged membranes showed no decline in hydraulic permeability. Filtration tests performed with concentrated culture media containing spores of B. subtilis led to a significant decrease in membrane hydraulic permeabilities (but less so with $\mathrm{Cu}$-exchanged membranes). The surfaces showed less effective global antifouling properties during the filtration of a concentrated culture medium due to competition between bacterial growth and the bactericidal effect of copper. Analyses of copper leached in solution show that after a conditioning step, the amount of copper released is negligible.

Keywords Bacterial growth investigation · Copper ion exchange $\cdot$ Mordenite membrane $\cdot$ Water permeability · Biofilm

\section{Introduction}

Membrane separation processes are popular in an array of fields as they use far less energy and chemical agents than competing processes (Zondervan et al. 2007). Membrane separation is also a "green" process as it works without added chemicals that would otherwise be a new source of pollution requiring further treatment (Nakao 1994).

Mineral membranes are widely used in industry for water purification or rectification and wastewater treatment $(\mathrm{Qu}$ 
et al. 2013), where they show decent performances and high chemical, thermal, and mechanical stabilities (Chevereau et al. 2010). One example is zeolite membranes, which are used in several filtration applications. Zeolites have uniform molecular-sized pores resulting in significant differences in transport rates for some molecules (Caro and Noack 2010; Chevereau et al. 2011). For example, mordenite membranes are prepared by seeded hydrothermal synthesis of a gel of Namordenite (active layer) impregnated on a tubular alumina support (Chevereau et al. 2011). However, these membranes are costly and can be reversibly or irreversibly fouled depending on the bond strength of particles or compounds with the membrane surface (Baker and Dudley 2011).

Irreversible fouling is usually caused by the development of biofilms and/or the mechanical sealing of pores. Recovering the initial filtration properties of the membrane requires chemical cleaning (acid/alkaline washing at high temperature) which is a step that interrupt the filtration operation. Manufacturers of reverse-osmosis membranes recommend intensive chemical cleaning every few months when operational water flux drops below $10 \%$ of initial flux (Ben-Sasson et al. 2014).

The use of an "antibacterial" membrane offers an alternative way to overcome these problems, which affect both the quality of the filtered solutions and the performance of the filtration process. The incorporation of metal ions in the active layer of the membranes can resolve and even prevent these problems by creating an unfavorable environment for bacterial growth (Li et al. 2008).

The antibacterial activity of several metals ( $\mathrm{Fe}, \mathrm{Zn}, \mathrm{Mn}$, $\mathrm{Co}, \mathrm{Cu}, \mathrm{Ni}, \mathrm{V}$, and $\mathrm{Mo}$ ) and their ions has been well investigated (Xu et al. 2010). Inefficiency, toxicity, or cost concerns mean that only some of these elements can viably be used in industrial applications. The focus of research has turned mainly to iron, silver, and copper which show good antimicrobial properties against a broad spectrum of prokaryote and eukaryote microorganisms (Grass et al. 2011; Sondi and SlopekSondi 2004; Yoon et al. 2007). In ionic form, these elements can alter the bacterial cell wall (and thus, modify cell membrane permeability), causing lysis that drains the cell of constituents (Friedman and Dugan 1968; Wilhelm and Daune 1969). Other investigations have shown that ionic metals can prevent cell proliferation by binding to DNA and inducing the inactivation of certain proteins involved in the energy metabolism, such as respiratory-chain cytochromes, causing the reduction of sulfhydryl groups (Feng et al. 2000; Liau et al. 1997). It is also hypothesized that metal ions may catalyze the formation of reactive oxygen species (ROS) that would attack the cellular constituents, causing their oxidation (Damm et al. 2008; Park et al. 2009; Yang et al. 2002). Microbial inactivation can also be achieved through direct-action contact with ionic metals. In vitro tests have demonstrated that bacteria including Escherichia coli, Staphylococcus aureus, Listeria monocytogenes, or Legionella pneumophila are sensitive to these ions, either in solution or immobilized on a support (Park et al. 2009).

Bacterial sensitivity to metal ions is species-dependent. Gram-negative species (Porphyromonas gingivalis, Prevotella intermedia, and Actinobacillus actinomycetemcomitans) are more ion-sensitive than gram-positive species (Streptococcus mutans, Streptococcus sanguis, Actinomyces viscosus, and $S$. aureus). It was speculated that the difference in sensitivity is at least partly due to the structure of the cell walls, which is the most marked difference between the two groups. Cell walls of gram-positive species contain from 3 to 20 times more peptidoglycan than gram-negative bacteria (Wicken 1985).

The main preventive technique used today is physical surface modification to minimize microorganism-support interaction and bacterial adhesion, and there is a large literature on the ability of surfaces immobilizing $\mathrm{Ag}^{+}$or $\mathrm{Cu}^{2+}$ to limit the development of biofouling and biofilm formation (Panácek et al. 2006).

For membrane filtration applications, several studies have demonstrated the potential of silver nanoparticles as biocides (Dror-Ehre et al. 2010; Ben-Sasson et al. 2014). Other studies have shown that metal ions substantially reduce the bacterial adhesion forces by changing surface hydrophobicity (Davis and Leckie 1978; Dong and Bell 1999). Zeolite membranes can be made hydrophilic or hydrophobic depending on the silica/alumina ratio used for the active layer coating the supports (Beving et al. 2008). The addition of metal ions like $\mathrm{Ag}^{+}$ and $\mathrm{Cu}^{2+}$ may cause a decrease in contact angle between water and membrane surface, which increases the hydrophilicity of the active layer and subsequently reduces the affinity for bacteria (Yang et al. 2002).

From this standpoint, a promising way forward could be to use a zeolite like Na-mordenite as mordenites with low $\mathrm{Si} / \mathrm{Al}$ ratios have high potential cation exchange (Schick et al. 2011). Indeed, $\mathrm{Na}^{+}$cations, which help offset the negative charges induced by the tetrahedral structure of zeolites, are preferably exchanged by other metal cations such as $\mathrm{Cu}^{2+}$, $\mathrm{Ag}^{+}, \mathrm{Zn}^{2+}, \mathrm{Fe}^{2+} / \mathrm{Fe}^{3+}$, and $\mathrm{Ti}^{4+}$ and confer bactericidal properties to the modified mordenite (Beving et al. 2008; De la Rosa-Gomez et al. 2010; Makita et al. 1999; Sabbani et al. 2010).

The aim of this study was to develop a new material with antibacterial and antifouling properties to ensure a sound and smooth filtration process. The analyses are conducted on flat plates (non-porous material) and tubular membranes (in filtration mode) presenting the same surface properties. First, we ran analyses conducted in static conditions using alumina plate supports coated with Na-mordenite (Na-Mor plate) and/or copper-exchanged Na-mordenite (Cu-Mor plate). Bacterial adhesion was investigated using an epifluorescence microscope. Second, we studied biofilm development on the different plates (Cu-Mor and Na-Mor plates) in dynamic- 
mode conditions, using confocal microscopy. In the last step, we tested the antimicrobial activity (bactericidal or bacteriostatic) of the functionalized membrane ( $\mathrm{Cu}-\mathrm{Mor}$ membrane) via the evolution in membrane permeability. All three sets of analyses systematically investigated the leaching of copper ions in test solutions.

\section{Materials and methods}

\section{Mordenite synthesis and copper exchange protocols}

Mordenite was prepared (in collaboration with the Institute for Research on Advanced Materials - IRMA, Ploemeur, France) following the procedure detailed in Hincapie et al. (2004). First, a gel was obtained by mixing two solutions of silica and alumina gels $\left(6 \mathrm{Na}_{2} \mathrm{O}: 1.5 \quad \mathrm{Al}_{2} \mathrm{O}_{3}: 30 \quad \mathrm{SiO}_{2}: 780 \mathrm{H}_{2} \mathrm{O}\right)$. This gel was impregnated by spin-coating inside tubular ceramic membranes provided by Pall Exekia (Bazet, France; $1 \mathrm{kDa}, \mathrm{Al}_{2} \mathrm{O}_{3} / \mathrm{TiO}_{2}$, internal diameter $=6.8 \mathrm{~mm}$, length $0.25 \mathrm{~m}$ ). Alumina plates ( $2 \mathrm{~cm}$ sides and $0.1 \mathrm{~cm}$ thick) were homogeneously coated with $350 \mu \mathrm{L}$ of gel using a micropipette. Na-mordenite was then produced by seeded hydrothermal synthesis at $155^{\circ} \mathrm{C}$ for $42 \mathrm{~h}$ in an autoclave. The elemental composition of the Na-mordenite is $\mathrm{Na}_{8} \mathrm{Al}_{8} \mathrm{Si}_{40} \mathrm{O}_{96} n \mathrm{H}_{2} \mathrm{O}$ (Limousy et al. 2013).

Copper-exchanged mordenite was obtained immersing the coated plates and tubular membranes in a solution of $\mathrm{CuSO}_{4}$ (1 M) at $60^{\circ} \mathrm{C}$ for $2 \mathrm{~h}$ and repeating the operation once. The plates and membranes were then rinsed with demineralized water for 30 min five times over, dripped under dry air compressed at 0.5 bar, and dried in an oven for $1 \mathrm{~h}$ at $80^{\circ} \mathrm{C}$. Copper content of the exchanged mordenite samples was estimated after scraping and mineralization from plate and membrane models by inductively coupled plasma technology (Ultima 2, Horiba). X-ray diffracton (XRD) analyses were performed with a PAN analytical X'Pert Pro diffractometer operating with $\mathrm{Cu} \mathrm{K} \alpha$ radiation $(\lambda=0.15418 \mathrm{~nm})$ to check the absence of crystalline phases other than zeolite. $\mathrm{Si} / \mathrm{Al}$ ratio was determined by wavelength-dispersive X-ray fluorescence (XRF) using a Philips MagiX (2.4 kW) apparatus.

\section{Plates and tubular membranes}

The antibacterial property of the active layers was investigated using square plates and tubular membranes. Three sets of alumina plates were used (Table 1): without coating (alumina plate), coated with $\mathrm{Na}$-mordenite (Na-Mor plate), and coated with copper-exchanged Na-mordenite ( $\mathrm{Cu}$-Mor plate). Filtration tests were conducted using three ceramic tubular membranes: without coating (ceramic membrane), coated with Na-mordenite (Na-Mor membrane), and coated with copper-exchanged Na-mordenite (Cu-Mor membrane). The detailed composition of the different plates and membranes is given in Table 1 .

\section{Setup}

\section{Shear cell}

Biofilm development on the plate surfaces was investigated by using a pilot shear cell (Fig. 1). Faille et al. (2013) showed that bacterial adhesion should be possible depending on the operating conditions (shear rate). This equipment makes it possible to study the effect of fluid dynamics on biofilm development on the different plate surfaces. The shear cell measures $30 \mathrm{~mm}$ of width, $15 \mathrm{~mm}$ of height, and $300 \mathrm{~mm}$ of length. For each test, eight plates were placed inside the cell and the level of the wall was precision-adjusted. Experiments were carried out at a fixed flow rate of 300 L.h ${ }^{-1}$ during 48 h. This flow rate induces the mean shear forces exerted on the plate surface at this flow rate is $0.17 \mathrm{~Pa}$, according to Blasius equation Eq. ((1).

$$
\tau_{p}=\frac{0.04 \rho V_{m}^{2}}{\operatorname{Re}^{0.25}} \quad \text { for } 3000<\mathrm{Re}<10^{5}
$$

Table 1 Composition of the plates and tubular membranes used in this study. (Mean amounts of zeolite deposited and copper exchanged are values taken from two samples used for microbiological culture tests and for measuring copper leaching)

\begin{tabular}{|c|c|c|c|c|}
\hline & Coating method & Designation & $\begin{array}{l}\text { Mean amount } \\
\text { of deposited zeolite }\end{array}$ & $\begin{array}{l}\text { Copper content } \\
\text { in the zeolite ( } \mathrm{wt} \%)^{*}\end{array}$ \\
\hline \multirow[t]{3}{*}{ Plates } & Without coating & Alumina plate & 0 & 0 \\
\hline & Na-mordenite & Na-Mor plate & $37.5 / 54 \mathrm{mg}$ & 0 \\
\hline & $\begin{array}{l}\text { Mordenite exchanged } \\
\text { with copper }\end{array}$ & $\mathrm{Cu}-$ Mor plate & $19 / 67 \mathrm{mg}$ & $3.6 / 3.9$ \\
\hline \multirow{3}{*}{$\begin{array}{l}\text { Tubular } \\
\text { membranes }\end{array}$} & Na-mordenite & Na-Mor membrane & $1.03 \mathrm{~g}$ & 0 \\
\hline & $\begin{array}{l}\text { Mordenite exchanged } \\
\text { with copper }\end{array}$ & $\mathrm{Cu}-\mathrm{Mor}$ membrane & $1.43 \mathrm{~g}$ & 3 \\
\hline & Without mordenite & Ceramic membrane & - & - \\
\hline
\end{tabular}

*Analysis method: induced coupled plasma (ICP) 


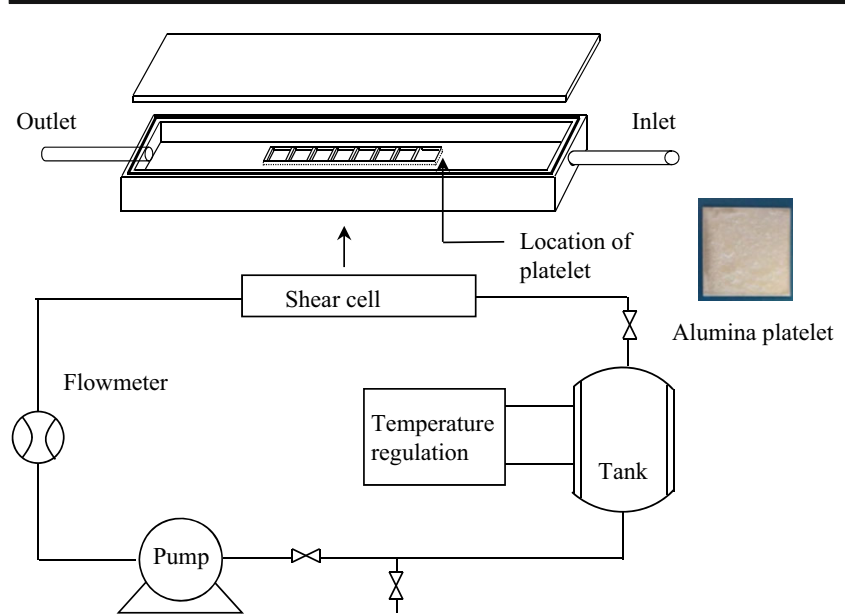

Fig. 1 Schematic diagram of the shear cell used for the experiments performed under dynamic conditions

where $\tau_{p}(\mathrm{~Pa})$ is average shear stress, $\rho\left(\mathrm{kg} \mathrm{m}^{-3}\right)$ is fluid density, $V_{\mathrm{m}}\left(\mathrm{m} . \mathrm{s}^{-1}\right)$ is average fluid velocity, and Re is Reynolds number.

This equation gives an estimation of the intensity of turbulence in the cell, especially close to the plates under study. The contaminated solution is assumed to have similar physical properties to pure water. Operating temperature is held at a constant $30^{\circ} \mathrm{C}$ throughout the tests.

\section{Ultrafiltration setup}

The antibacterial and antifouling activities of the tubular membranes were investigated using a lab-scale filtration pilot (Fig. 2). The solution was in a feed tank and fluid circulation was impelled by a volumetric pump (flow rate $=200 \mathrm{~L} \cdot \mathrm{h}^{-1}$ ). Pressure was measured by two sensors upstream and downstream of the membrane and was controlled by a manual valve. Temperature was held at a constant $25^{\circ} \mathrm{C}$ throughout circulation in a counter-current heat exchanger cooled by a chiller unit.
The operation was performed with total recycling of the water permeate in the feed tank except the permeate and retentate sampled for analysis.

Before each microbiological experiment, a conditioning step using demineralized water was performed to stabilize the hydraulic properties of the membrane (Bikai et al. 2015). This step is needed to get steady hydraulic performances. Consequently, a modification of the hydraulic permeability will be assigned to biofilm formation or membrane sealing. For this, water permeation flux $\left(J_{W}\right)$ was measured for various transmembrane pressures $\Delta P(1,2,3,4$, and 5 bar $)$, and membrane permeability $\left(L_{p}\right)$ was estimated using Eq. ((2):

$J_{W}=\frac{L_{p}}{\mu} \Delta P$

where $\mu$ is the dynamic viscosity (Pa.s) of pure water, $J_{w}$ is water permeation flux $\left(\mathrm{m}^{3} \cdot \mathrm{m}^{-2}\right.$ memb. $\left.{ }^{-1}\right), L_{p}$ is hydraulic permeability $\left(\mathrm{m}^{3} \cdot \mathrm{m}^{-2}\right.$ memb), and $\Delta P$ is transmembrane pressure $(\mathrm{Pa})$.

Filtration experiments were carried out at 5 bar transmembrane pressure using a suspension of bacteria at an initial concentration of $10^{5}$ CFU. $\mathrm{mL}^{-1}$, first in $2 \mathrm{~L}$ of demineralized water and second in $2 \mathrm{~L}$ of a concentrated nutrient medium.

The hydrodynamic parameters of the different configurations tested in shear cell and filtration setups are reported in Table 2.

\section{Microorganisms and culture medium}

Bacterial sensitivity to metal ions is widely related to cell membrane structure, so here we tested two categories of microorganisms presenting different cell wall structures. The distinction was based on gram-stain tests. Gram-positive bacteria are considered more resistant to metal ions action than gram-negative bacteria due to their thicker peptidoglycan (Prescott et al. 2003). In this study, E. coli strain ATCC 25922 (ref. no. 0335P, MicroBioLogics) and S. aureus strain ATCC 6538P (ref. no. 0827P, MicroBioLogics) were used as gram-negative and
Fig. 2 Schematic illustration of the ultrafiltration setup

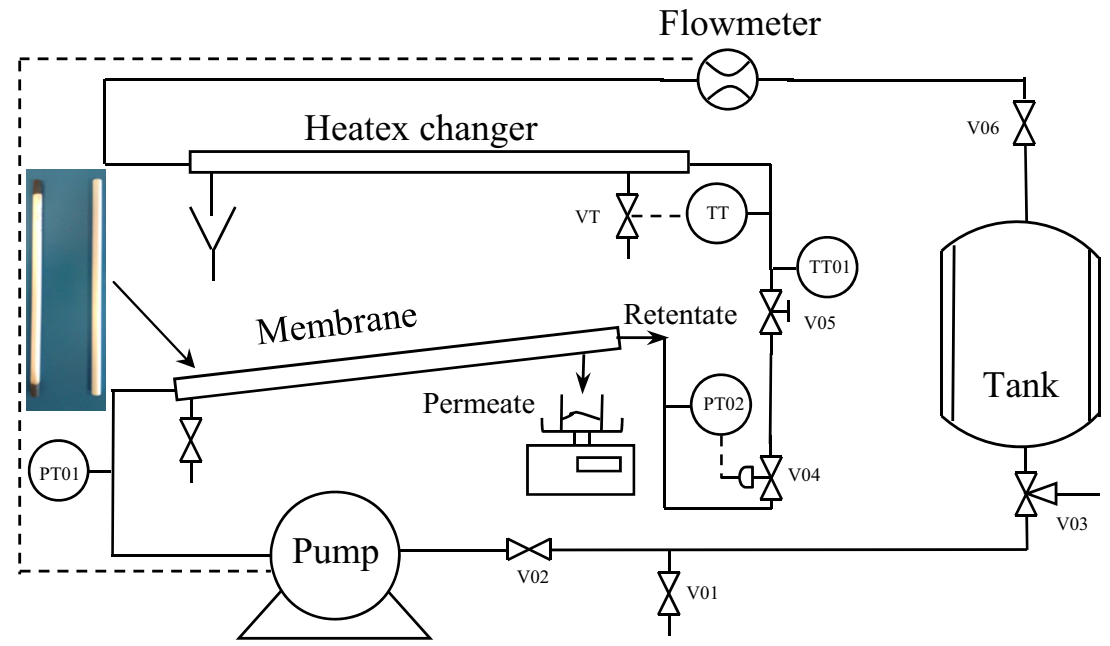


Table 2 Operating hydrodynamic conditions of the experimental tests

\begin{tabular}{llllll}
\hline & Flow rate $(1 / \mathrm{h})$ & Mean velocity $(\mathrm{m} / \mathrm{s})$ & Mean shear stress $(\mathrm{pa})$ & Transmembrane pressure (pa) & Reynolds number \\
\hline Shear cell experiments & 300 & 0.185 & 0.17 & - & 4643 \\
Filtration experiments & 200 & 1.5 & - & $10^{5}$ to $510^{5}$ & 11,660 \\
\hline
\end{tabular}

gram-positive bacteria, respectively. The antifouling property of tubular zeolite membranes was also analyzed using Bacillus subtilis spores (CUETM 98/7, provided by the Pasteur Institute, Paris, France) due to their high resistance to heat treatment and standard clean-in-place procedures.

Concentration of E. coli bacteria (in demineralized water) was kept constant during the filtration tests. A sample of the solution was taken each day, and the following day bacterial detection and counting was performed on the sample before starting a new filtration test. Starting from these results, bacterial concentration was adjusted by direct inoculation to reach $10^{5}$ CFU.mL ${ }^{-1}$.

The nutrient medium was used in concentrated or diluted form to investigate concentration-related impacts on bacterial growth and the antibacterial and the antifouling effects of the active layer. The nutrient medium was composed of meat extract $\left(5\right.$ g. $\left.\mathrm{L}^{-1}\right)$, yeast extract $\left(2 \mathrm{~g} . \mathrm{L}^{-1}\right)$, and peptone $\left(5 \mathrm{~g} . \mathrm{L}^{-1}\right)$ and was considered as concentrated. For the shear stress analyses, this nutrient medium was diluted by a factor of 5 .

\section{Experimental protocols}

\section{Titration of leached copper ions}

Copper is often considered as toxic above a certain threshold, making it important to monitor the amount of copper leached into the medium during the experimental tests to validate the efficiency of the ionic exchange. The stability of the exchanged cations $\left(\mathrm{Cu}^{2+}\right)$ was verified according to hydrodynamic conditions. We, thus, verified copper mass balance during experimental tests.

Experimentation consisted in monitoring the electric conductivity of the medium containing leached copper ions. After stabilization, the amount of copper was measured by atomic absorption spectrophotometry. These analyses were performed after experiments carried out with plates and tubular membranes, respectively. The plates were placed in a beaker containing $20 \mathrm{~mL}$ of demineralized water and electric conductivity was measured continuously while stirring the beaker at $150 \mathrm{rpm}$. For tubular membranes, analyses were performed on permeate and retentate samples resulting from the membrane-conditioning step. The conditioning step enables the membrane hydraulic properties to stabilize and avoids unwanted copper release during filtration of contaminated solutions. Antibacterial activity is, thus, due exclusively to the $\mathrm{Cu}$-mordenite layer coating the membranes.
Microbiological analyses

The antibacterial activity of $\mathrm{Cu}-\mathrm{Mor}$ plates was estimated according to standard ISO 22196 (2007). This method consists in inoculating the tested plates with a fixed volume of bacterial cells. Thus, $100 \mu \mathrm{L}$ of test inoculum was used at $10^{6}$ CFU.mL $\mathrm{mL}^{-1}$ bacterial concentration. Plates were covered with a plastic film. Immediately after inoculation, a first set of plates was washed with $10 \mathrm{~mL}$ of SCDLP broth (soybean casein digest lecithin polysorbate 80 Medium according to ISO 22196) and number of viable bacteria $\left(\mathrm{h}_{0}\right)$ was estimated by counting. The second set of plates (same characteristics as the first) was treated after incubation following the same protocol as described above to determine the number of viable cells after $24 \mathrm{~h}\left(\mathrm{~h}_{24}\right)$.

The plates contaminated with the two different strains were analyzed by epifluorescence microscopy in order to verify the presence of live or dead microorganisms adhering to the plate surfaces. The protocol used a live/dead fluorochrome employing two nucleic acid stains: green-fluorescent SYTO® 9 stain to identify dead cells and red-fluorescent propidium iodide stain to identify viable cells. Each plate analyzed was rinsed with sterile water to remove non-adherent bacteria.

The analyses carried out in the shear cell were performed with $4 \mathrm{~L}$ of a diluted nutrient solution contaminated with bacteria (E. coli or S. aureus) at a concentration of $10^{5}$ CFU. $\mathrm{mL}^{-1}$. Experiments were conducted in dynamic-flow conditions for $48 \mathrm{~h}$ at a constant temperature of $30^{\circ} \mathrm{C}$. Then, the different plates were rinsed and analyzed by confocal microscopy to verify the development of a biofilm and determine its thickness. Counting was also performed on the contaminated solutions for real-time monitoring of bacterial population.

\section{Results and discussion}

\section{Verification of the antibacterial activity of treated alumina plates under static flow conditions}

Investigation of antibacterial activity by direct contact

Antibacterial activity under static flow conditions was analyzed using solutions contaminated with $E$. coli and $S$. aureus. The analyses were performed in triplicate.

Counts performed immediately post-inoculation and after washing the alumina plates $\left(\mathrm{h}_{0}\right)$ showed bacterial 
concentrations close to the initial bacterial concentration of $10^{5}$ CFU.mL ${ }^{-1}\left(2.12( \pm 0.33) 10^{4}\right.$ and $7( \pm 1)$ $10^{4} \mathrm{CFU} \mathrm{mL} \mathrm{m}^{-1}$ for E. coli and $S$. aureus, respectively). This result shows that alumina plates have a moderate specific antibacterial activity after a short contact time. Moreover, analyses carried out after $24 \mathrm{~h}\left(\mathrm{~h}_{24}\right)$ showed bacterial growth $(5.43$ $( \pm 0.51) 10^{4}$ CFU.mL ${ }^{-1}$ for E. coli and $2.54( \pm 0.25)$ $10^{6}$ CFU.mL ${ }^{-1}$ for S. aureus (Fig. 3)).

Figures 4 and 5 show epifluorescence microscopy observations of viable (green spots) and dead cells (red spots) for E. coli on the alumina plates (h0 and h24) and the $\mathrm{Cu}-\mathrm{Mor}$ plates (h24). Alumina plates showed high bacterial adhesion for the two strains at $\mathrm{h}_{0}$ and after $24 \mathrm{~h}\left(\mathrm{~h}_{24}\right)$. Cu-Mor plates showed zero residual contamination (no green or red spots on the surface). The $\mathrm{Cu}$-exchanged mordenite layer induces the inhibition of the bacterial activity regardless of cell wall structure (gram-positive and gram-negative) after $24 \mathrm{~h}$ of incubation.

Figure 5 shows the same analysis performed with solutions containing $S$. aureus. Microscopy observations showed that higher concentrations of adhered bacteria at $\mathrm{h}_{24}$ and confirmed the counting results. The presence of live and dead bacteria (in lower proportions) was also observed on alumina plates, whereas $\mathrm{Cu}-$ Mor plates showed non-adhesion of viable or dead cells. This result indicates that the use of $\mathrm{Cu}$-mordenite as surface layer induced antibacterial and antifouling effects against both strains tested.

\section{Diffusive action of copper ion}

Two analyses performed by stirring $\mathrm{Cu}-$ Mor plates in a bacterial suspension of $E$. coli $\left(10^{5}\right.$ CFU. $\left.\mathrm{mL}^{-1}\right)$ showed absence of bacteria in the solution after $24 \mathrm{~h}$ of incubation at $37^{\circ} \mathrm{C}$.

The analyses carried out using atomic absorption spectrophotometry showed that the amounts of leached copper ions on the two $\mathrm{Cu}-$ Mor plates studied were 0.05 and

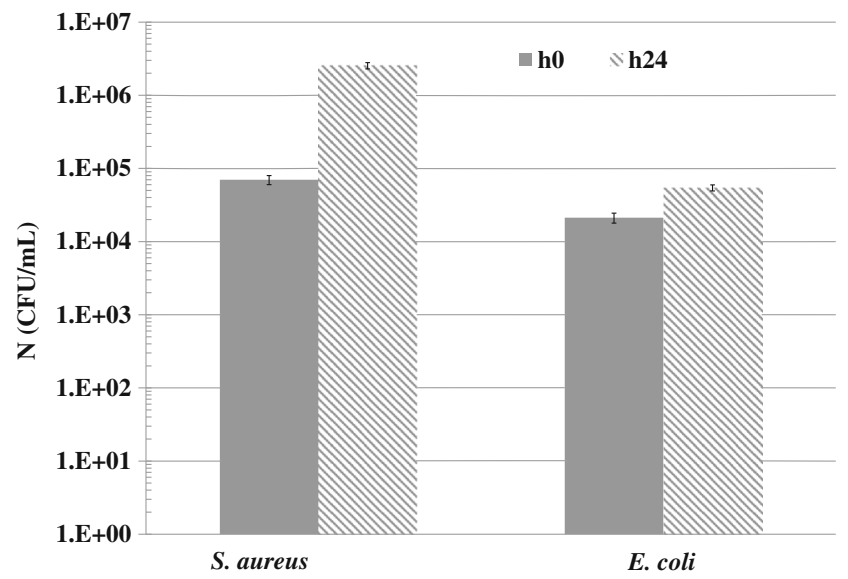

Fig. 3 Bacterial concentration of E. coli and $S$. aureus strains at $\mathrm{h}_{0}$ and $\mathrm{h}_{24}$ incubation times, measured according to ISO 22196 protocol, after contact with alumina plates
$0.082 \mathrm{mg}$, i.e., 7 and $3 \%$ of the initial deposited copper, respectively. These results showed that the plates remain functionalized after stirring. XRD analysis of the Na-mordenite and $\mathrm{Cu}$-mordenite layers were performed to determine the structure of the crystalline materials (Fig. 6). The different XRD patterns show reflection intensities $\left(22.3^{\circ}, 25.7^{\circ}, 26.3\right.$ $\circ, 27.9^{\circ}$, and $30.8^{\circ}$ ) corresponding to the mordenite crystalline framework, with no difference when $\mathrm{Cu}^{2+}$ cations replaced $\mathrm{Na}^{+}$cations. XRF analysis performed on these materials showed that they both have a $\mathrm{Si} / \mathrm{Al}$ ratio of 6 .

The absence of a specific peak attributable to copper demonstrates the absence of copper metallic particles at the surface of the zeolite. Only $\mathrm{Cu}^{2+}$-exchanged cations are present in the corresponding materials.

$\mathrm{XRF}$ analysis was confirmed by the filtration tests led during the conditioning stage on ceramic, Na-Mor and $\mathrm{Cu}-\mathrm{Mor}$ membranes (Fig.7). Indeed, Na-Mor and Cu-Mor membranes showed similar hydraulic permeabilities $\left(3.5 \times 10^{-14}\right.$ and $3.3 \times 10^{-14} \mathrm{~m}^{3} \mathrm{~m}^{-2}$ memb for Cu-Mor and Na-Mor membranes, respectively). The slightly higher increase in permeability of the $\mathrm{Cu}-\mathrm{Mor}$ membrane remained non-significant during the 3 days of analysis. This result shows that the ion exchange had little or no effect on membrane hydraulic permeability. This is not a surprising finding, as copper ions are essentially present inside the crystal lattice (intracrystalline porosity), whereas the hydraulic permeability of the membrane is mainly driven by intercrystalline spaces due to the mordenite crystal agglomeration. However, both these membranes showed a significant drop in permeability compared to the ceramic membrane due to the change in porosity induced by the mordenite layer.

\section{Verification of the antibacterial activity of the $\mathrm{Cu}$-mordenite layer under dynamic flow conditions}

Biofilm development was investigated on the different plates and tubular membranes under dynamic conditions. Indeed, microorganism transport from solution to wall, bacterial adhesion, and biofilm consolidation were dependent on hydrodynamic conditions.

\section{Analyses in a shear cell (dynamic mode)}

The effect of the dynamic flow conditions on biofilm development at the surface of the different plates was studied using a shear cell (Fig. 1). Tests were performed on $\mathrm{Na}-\mathrm{Mor}$ and $\mathrm{Cu}-$ Mor plates with nutrient media contaminated with $E$. coli or $S$. aureus bacteria at the concentration of $10^{5} \mathrm{CFU} \cdot \mathrm{mL}^{-1}$ at $30{ }^{\circ} \mathrm{C}$ at a flow rate of $300 \mathrm{~L} \cdot \mathrm{h}^{-1}$.

Figure 8 a shows the biofilm thickness obtained after $48 \mathrm{~h}$ on Na-Mor plates. Biofilm thickness was strain-dependent and was around $20 \mu \mathrm{m}$ for $E$. coli bacteria and $10 \mu \mathrm{m}$ for $S$. aureus. The thickness difference of the biofilms can be explained by the difference in size of the two bacteria. Microscopy observations 
Fig. 4 Epifluorescence microscopy observations of dead and viable $E$. coli cells deposited on the surface of the different flat plates at $h_{0}$ and $h_{24}$

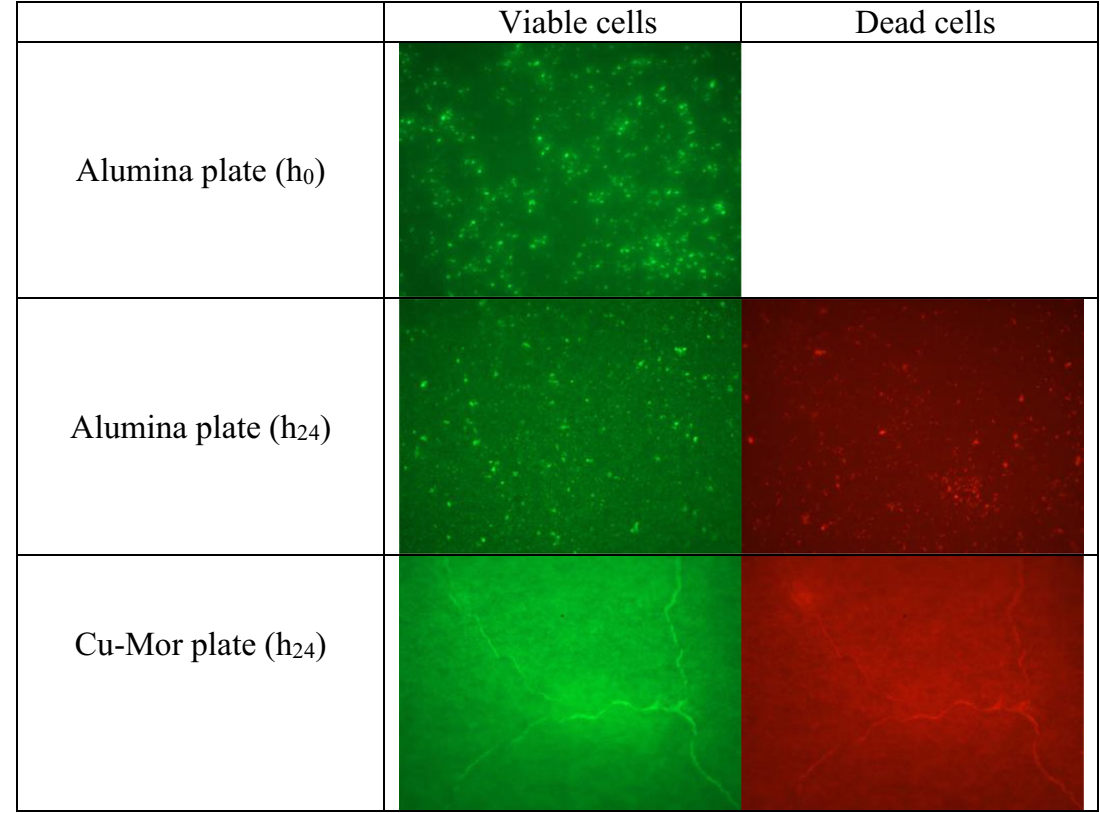

(Fig. 8b) showed that biofilms are formed by both viable (green color) and dead (red color) cells. The yellow color reflects the aggregation of viable and dead cells.

The same investigation performed with $\mathrm{Cu}$-Mor plates showed an absence of biofilm. Plate surfaces showed only a few adhered bacteria (Fig. 9). This same observation was found for both bacterial strains.

These results showed that copper ions subsequently reduce bacterial adhesion. This can be explained by the antibacterial properties of copper ions and the increase of surface hydrophilicity after ion exchange. The presence of nutrients at low concentrations in the medium did not modify the previous results.

\section{Effect of the Cu-mordenite layer on the filtration efficiency of tubular membranes}

The antimicrobial activity (bactericidal or bacteriostatic) of the $\mathrm{Cu}$-Mor membrane was studied during filtration tests. First, changes in hydraulic properties of both membranes were investigated to estimate the effect of the coating process (with Na-mordenite or $\mathrm{Cu}$-mordenite). Copper release in the solution was measured in parallel.

\section{a) Filtration tests on an aqueous solutions containing E. coli bacteria}

The first filtration tests were carried out using the ceramic membrane and the $\mathrm{Cu}$-Mor membrane (Fig. 10). The solution was an aqueous suspension of $E$. coli at a concentration of $10^{5} \mathrm{CFU} \cdot \mathrm{mL}^{-1}$. During these tests, the temperature was held at a constant $25{ }^{\circ} \mathrm{C}$ and bacterial concentration was monitored and adjusted every day to a constant $10^{5}$ CFU.mL ${ }^{-1}$. As detailed in the experimental part, the membrane properties were pre-stabilized (conditioning step) by filtration of demineralized water (Bikaï et al. 2015). Figure 10 shows the evolution of the hydraulic permeability of both membranes (ceramic and $\mathrm{Cu}-\mathrm{Mor}$ membranes).
Fig. 5 Epifluorescence microscopy observations of dead and viable $S$. aureus cells deposited on the surface of the different flat plates at $\mathrm{h}_{0}$ and $\mathrm{h}_{24}$

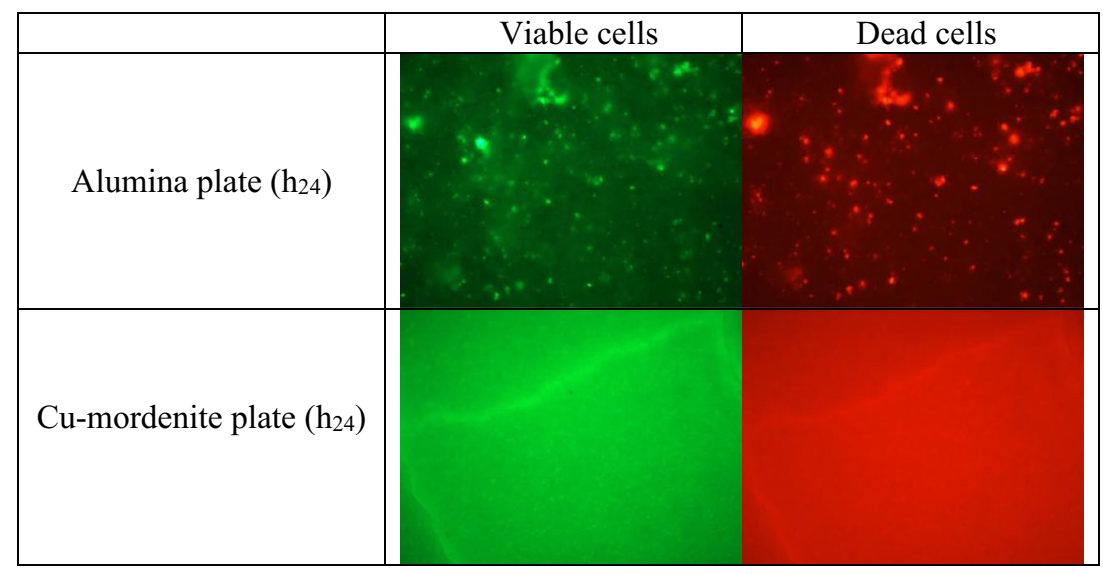




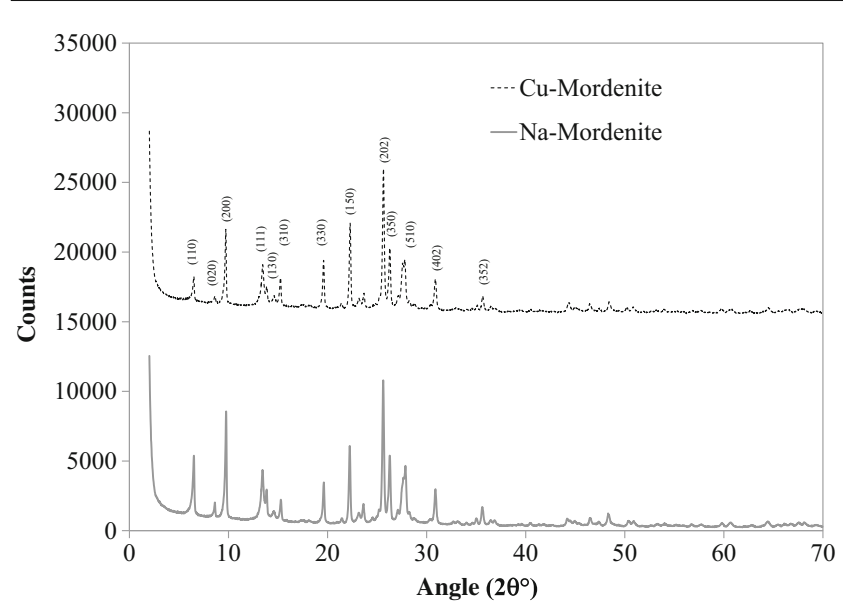

Fig. 6 X-ray diffractograms of Na-mordenite and $\mathrm{Cu}$-mordenite

First, the hydraulic permeability of the Cu-Mor membrane after the conditioning step was less than half the permeability of the ceramic membrane $\left(1.6 \times 10^{-14}\right.$ and $4.1 \times 10^{-14} \mathrm{~m}^{3} \cdot \mathrm{m}^{-2}$ memb, respectively). This decrease is due to the addition of a mordenite layer which tends to lower the porosity of the membrane and increase hydraulic resistance. This layer provides a homogeneous porosity at the membrane surface with uniform pore sizes.

Filtration tests on the contaminated solution found that hydraulic permeability decreased, especially with the ceramic membrane. For the $\mathrm{Cu}$-Mor membrane, adding bacteria had less effect on permeability. Indeed, the hydraulic permeability of the ceramic membrane halved rapidly from 4.1 to $1.9 \times 10^{-14} \mathrm{~m}^{3} \mathrm{~m}^{-2}$ memb (40\% during the first $150 \mathrm{~h}$ ) while the $\mathrm{Cu}$-Mor membrane permeability declined steadily from $1.5 \times 10^{-14} \mathrm{~m}^{3} \mathrm{~m}^{-2}$ memb and subsequently remained steady at around $0.9 \times 10^{-14} \mathrm{~m}^{3} \mathrm{~m}^{-2}$ memb.

At the same time, the $\mathrm{Cu}$-Mor membrane had a bactericidal effect, as bacterial concentration decreased each day. Microbiological analyses showed the absence of surviving bacteria in the permeate and less than $10^{2} \mathrm{CFU} \cdot \mathrm{mL}^{-1}$ of viable

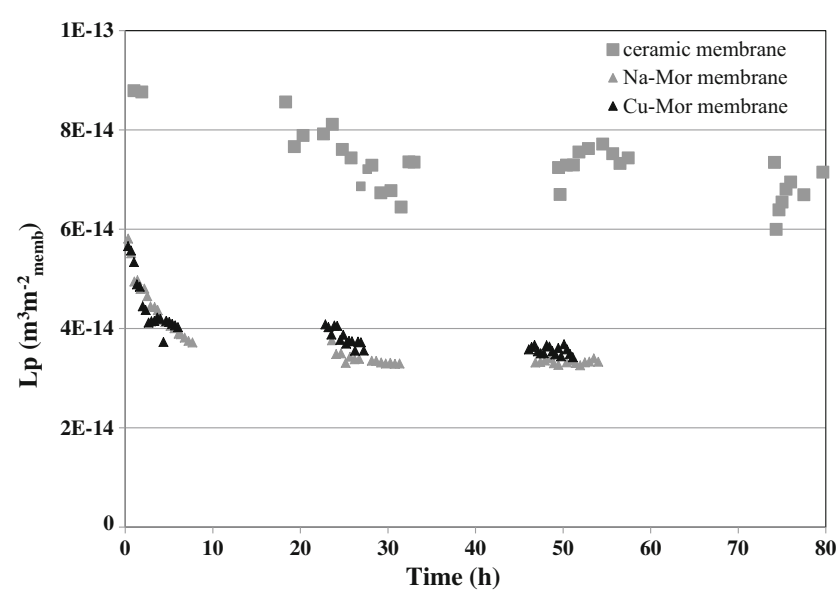

Fig. 7 Time-course change in hydraulic permeabilities of the ceramic, $\mathrm{Na}-\mathrm{Mor}$ and $\mathrm{Cu}-\mathrm{Mor}$ membranes during the conditioning stage bacteria in the retentate. The $\mathrm{Cu}-\mathrm{Mor}$ membrane showed antifouling properties given the minor decrease in hydraulic permeability during filtration tests compared to the ceramic membrane.

We investigated the amount of copper leached into solution during the condition step. During the conditioning step, $6 \mathrm{mg}$ of copper was released in the retentate relative to $43 \mathrm{mg}$ deposited, and no trace of copper ions was found in the permeate. Analyses performed in retentate and permeate during filtration tests showed that the membrane remains functionalized (no copper leached). Thus, a conditioning step is necessary in order to avoid potential contamination of the filtered medium by copper ions. Weakly bonded copper ions are therefore leached and the $\mathrm{Cu}$-Mor membrane remains functionalized.

\section{b) Filtration tests on a suspension of B. subtilis spores in a culture medium}

To gain further insight into the antimicrobial activity of the $\mathrm{Cu}-\mathrm{Mor}$ membrane, filtration tests were performed with a concentrated culture medium-containing B. subtilis spores. The culture medium was chosen to promote bacterial growth and was also used to check that observations in demineralized water and low-nutrient-concentration media were valid in high-nutrient-concentration media.

These tests used two membranes: a tubular mordenite membrane (Na-Mor membrane) and a tubular $\mathrm{Cu}$-mordenite membrane (Cu-Mor membrane). The use of the same coating material results in identical initial permeabilities after the conditioning step (Fig. 7), and thus, provides a better understanding of the effect of copper in the antifouling action.

Figure 11 illustrates the change in permeability of both membranes during the filtration stage.

During the filtration tests carried out with conditions conducive to biofilm development, the culture medium was only inoculated on the first day at a concentration of $10^{5} \mathrm{CFU} \cdot \mathrm{mL}^{-1}$ of $B$. subtilis spores. Counts were done at the end of each day. Figure 11 shows that permeability decreased for both $\mathrm{Cu}-\mathrm{Mor}$ and Na-Mor membranes, although less so Cu-Mordenitecoated membranes with than Na-Mordenite alone, even though the untreated membrane showed greater permeability on the first day. Indeed, at day three of filtration tests, permeability was $2.1( \pm 0.2) 10^{-15} \mathrm{~m}^{3} \mathrm{~m}^{-2}$ memb and $1.5( \pm 0.05)$ $10^{-15} \mathrm{~m}^{3} \mathrm{~m}^{-2}$ memb for $\mathrm{Cu}-$ Mor and Na-Mor membranes, respectively.

Figure 11 also shows that permeability decreases sharply with the $\mathrm{Cu}-M o r$ membrane during the four first hours compared to the Na-Mor membrane. A possible explanation may be the release of proteins from $B$. subtilis during the first hours of filtration. The presence of copper at the surface of the membrane and in the solution (leached part) may cause a rapid and significant release of protein (mainly in the form of enzymes) from the bacterial cell wall, as previously observed (Tong 
Fig. 8 Confocal microscopy observations on Na-Mor plates

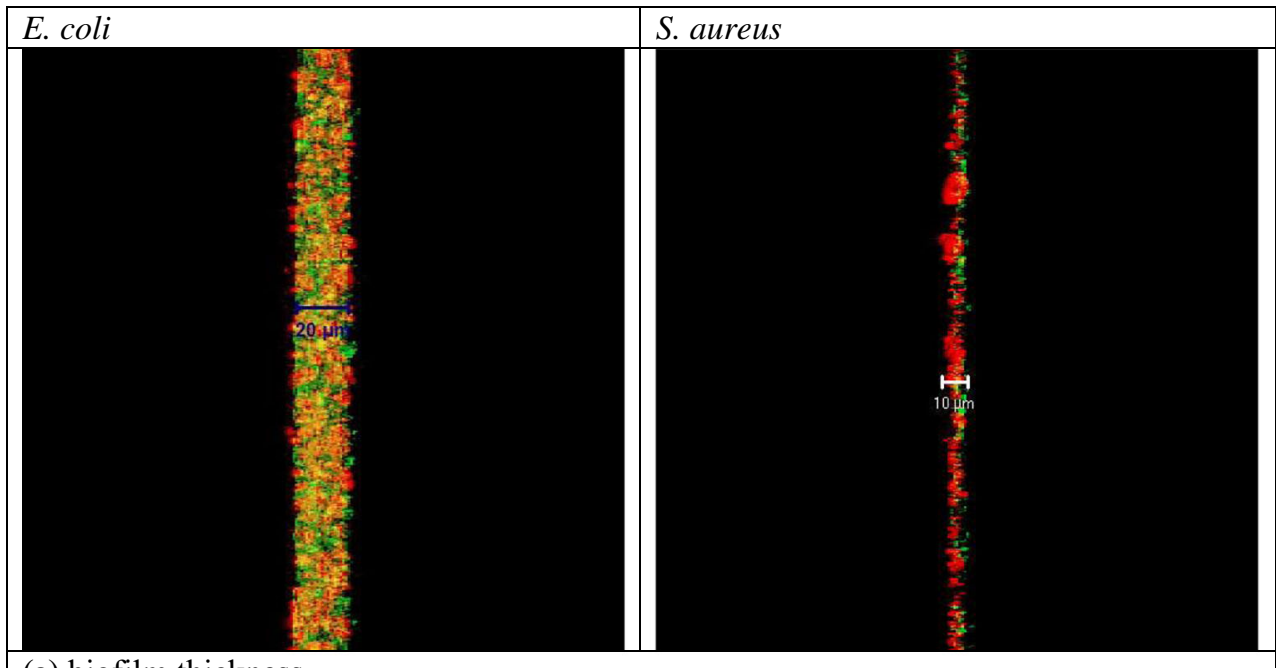

(a) biofilm thickness

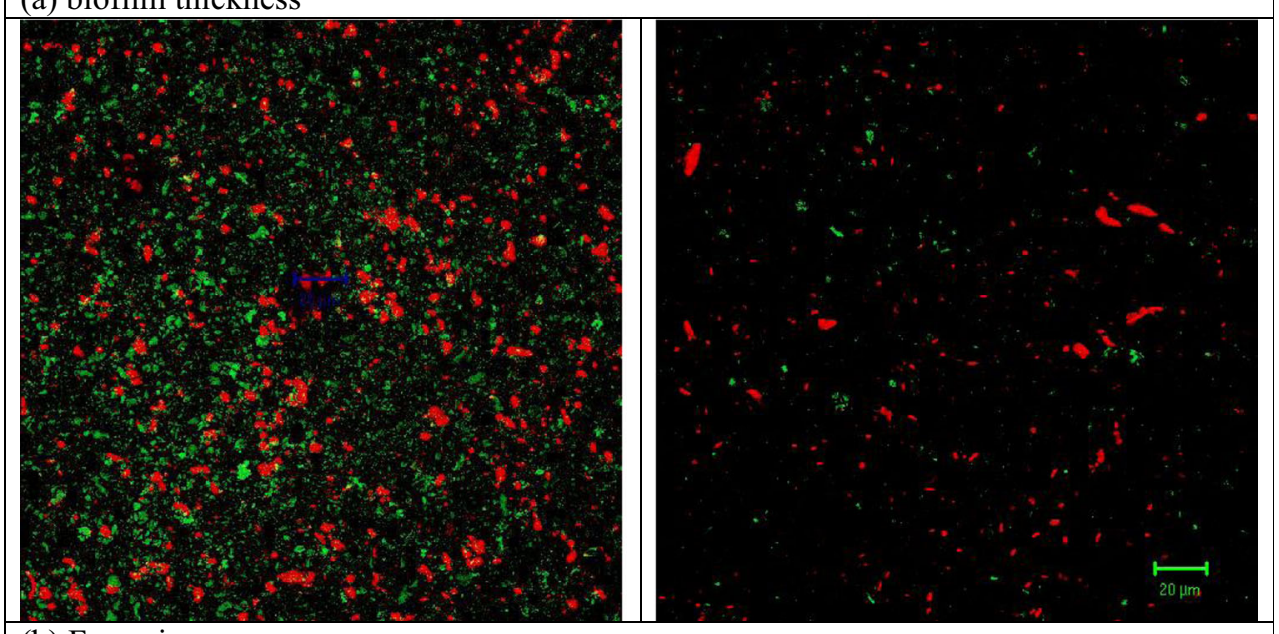

(b) Face view et al. 2005). Protein adsorption at the surface of the membrane as well as in the pores may trigger the sharp decrease in hydraulic permeability, in what is a partially reversible process. With the $\mathrm{Cu}$-Mor membrane, permeability for days 2 and 3 started higher and decreased more gradually throughout the filtration test; whereas with the Na-Mor membrane, permeability remained constant during days two and three. This result could be explained by detachment of the biofilm layer
Fig. 9 Confocal microscopy observations on $\mathrm{Cu}$-Mor plates

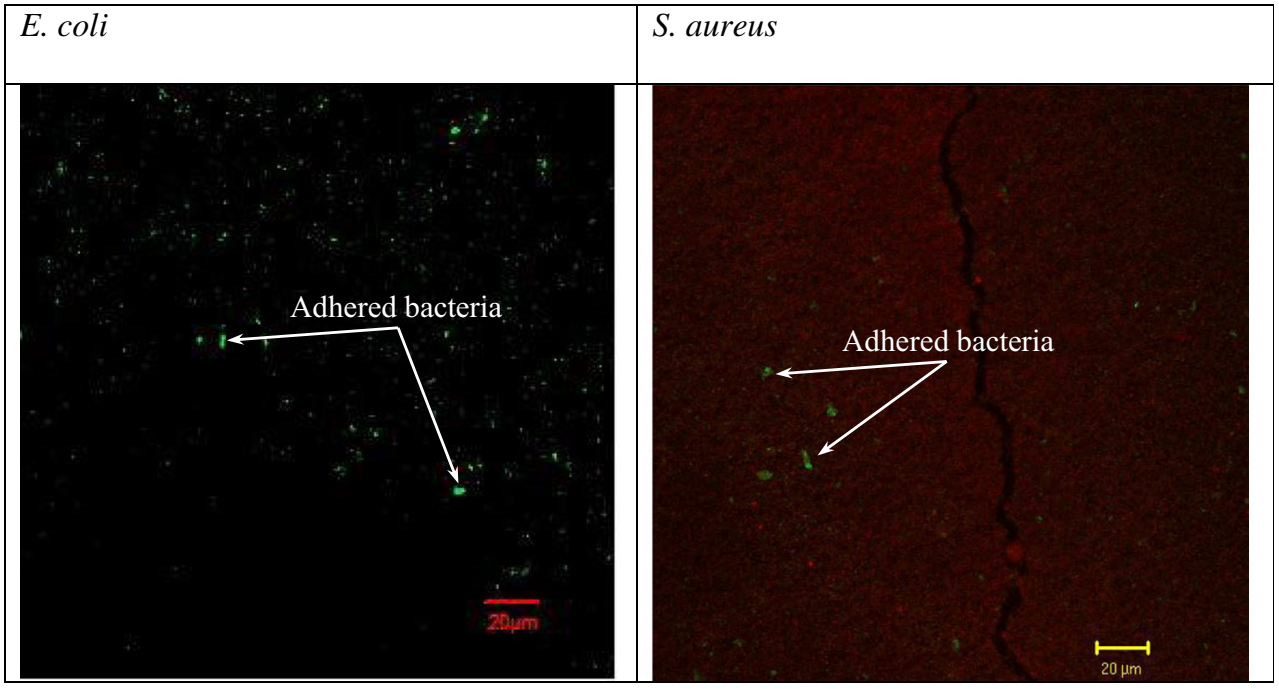




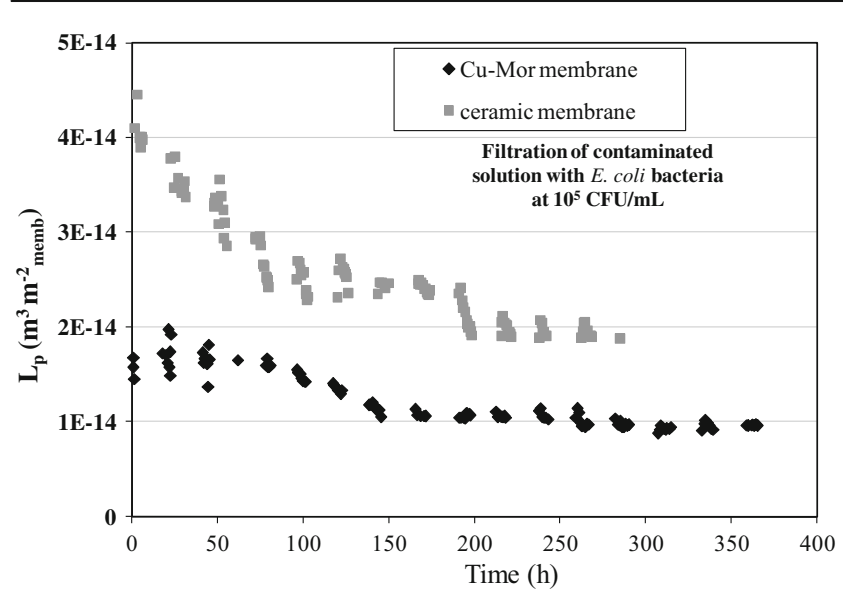

Fig. 10 Time-course change in hydraulic permeabilities of the ceramic and $\mathrm{Cu}-\mathrm{Mor}$ membranes during experiments carried out in the presence of E. coli bacteria

formed during filtration tests due to the weak adhesion forces developed at the surface of the $\mathrm{Cu}$-Mor membrane. This behavior confirms the role of copper in increasing the hydrophilicity of the mordenite layer surface, which subsequently reduces the biocompatibility of the membrane, and ultimately, the formation of biofilm.

Bacterial analyses showed that bacterial count increased during all 3 days of filtration (Fig. 12), especially for the NaMor membrane; whereas for the $\mathrm{Cu}$-Mor membrane, bacterial count was stable during days 1 and 2 before increasing again during day 3 . The difference in the number of bacteria between the two membranes can explain the observed hydraulic permeability gap. Bactericidal and antifouling behaviors observed during the filtration tests using an aqueous suspension of $E$. coli and $S$. aureus were not fully confirmed in this part of the experiment. Indeed, the high concentration of the nutrient medium used reduces the efficiency of copper ions exchanged on the mordenite layer. This effect is observed in the permeability values, which were slightly higher than for the Na-Mor membrane, but also in the number of bacteria in the solution,

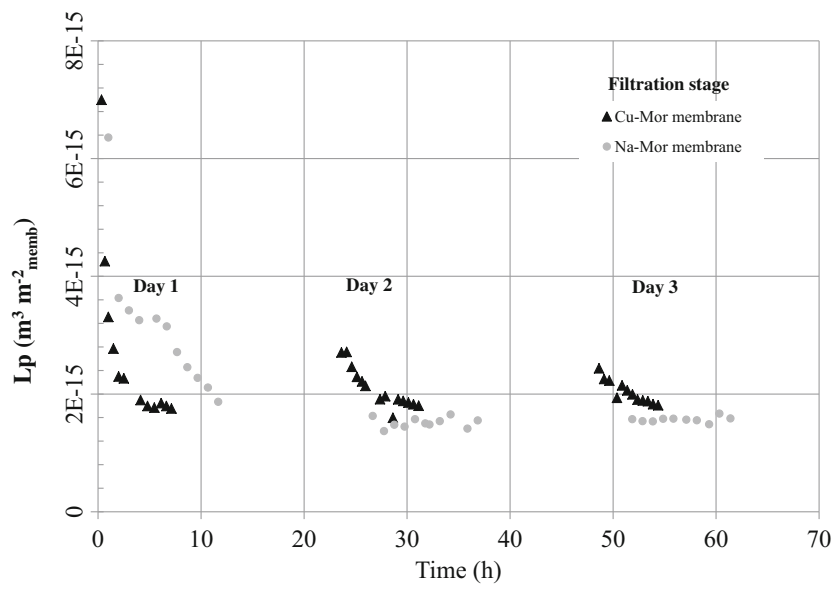

Fig 11 Hydraulic permeabilities of Na-Mor and $\mathrm{Cu}$-Mor membranes during experiments carried out in the presence of $B$. subtilis spores

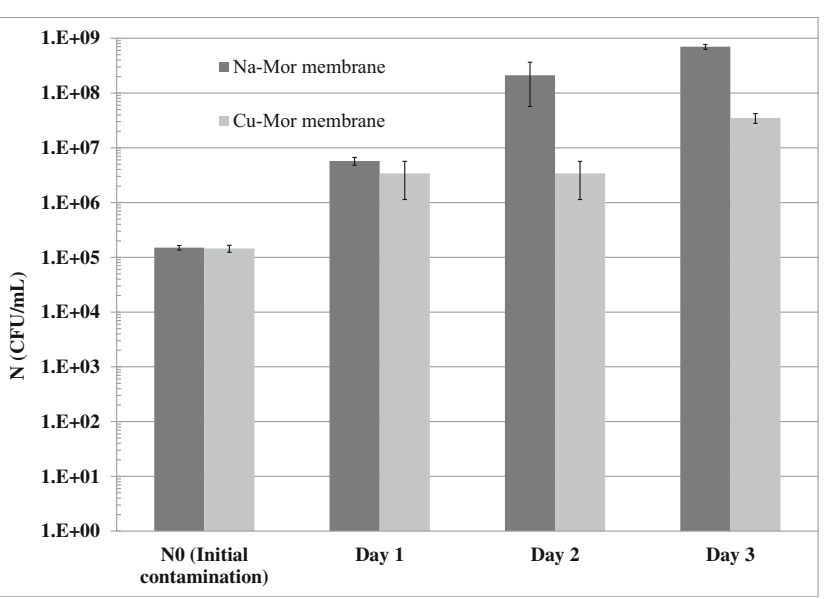

Fig 12 Concentration of $B$. subtilis bacteria during the filtration tests with $\mathrm{Na}-\mathrm{Mor}$ and $\mathrm{Cu}-\mathrm{Mor}$ membranes

which continues to increase. As filtration tests with a suspension of $E$. coli in demineralized water show that bacterial concentration decreased each day, there is clearly competition between the bactericidal effect of copper ions and bacterial growth in the high-nutrient-concentration medium.

The analyses of copper content at the end of the conditioning stage found no copper ions in the permeate, whereas a small amount had been leached into the retentate $(11 \mathrm{mg}$, approximatively $25 \%$ of the initial amount of exchanged copper). For the filtration stage, no trace of copper ions was detected both in either permeate or retentate samples.

\section{Conclusion}

The antibacterial activity of coated surfaces with or without copper exchange of the mordenite layer was tested on three types of bacteria: E. coli, S. aureus, and B. subtilis. The first result, obtained in static conditions, showed that $\mathrm{Cu}$-Mor plates have antibacterial activities even at higher bacterial concentrations $\left(10^{5} \mathrm{CFU} \cdot \mathrm{mL}^{-1}\right)$ and regardless of type of bacterium. Analyses carried out under dynamic conditions in a shear cell showed biofilm formation at the surface of alumina plates, with biofilm thickness being strain type-dependent, but not on $\mathrm{Cu}$-Mor plates, thus confirming the biofilm-preventive antifouling behavior of the $\mathrm{Cu}$-mordenite layer.

Filtration tests were conducted on contaminated solutions to study biofilm formation at the membrane surface under various hydrodynamic conditions. The biofilm probably induces polysaccharide secretion as a consequence of hydraulic stress, and as it develops on the surface, it changes membrane porosity by modifying the properties of the filtration layer.

Filtration tests performed with an aqueous suspension of $E$. coli and a culture medium containing $B$. subtilis spores showed a significant decline in hydraulic permeability with the ceramic membrane compared to the functionalized 
membrane. This finding showed that using a $\mathrm{Cu}-\mathrm{Mor}$ membrane could be of interest for filtering contaminated solutions. The presence of copper inhibited the formation of a biofilm on the membrane active layer and helped preserve membrane performances. Antifouling properties were less efficient for filtration of a concentrated culture medium. The presence of nutrients in addition to bacteria almost certainly modifies the surface properties of the $\mathrm{Cu}$-mordenite layer, and consequently, promotes bacterial growth. Titrations of copper ions showed that leached amount is negligible after conditioning compared to the amount initially exchanged.

This study finds that $\mathrm{Cu}$-Mor membranes presenting antifouling and antibacterial activities have potentially valuable applications for filtering low-nutrient-concentration media, as they can improve filtration process efficiency while reducing the cost of cleaning and disinfection operations.

\section{References}

Baker JS, Dudley LY (1998) Biofouling in membrane systems - a review. Desalination 118:81-98

Ben-Sasson M, Lu X, Bar-Zeev E, Zodrow KR, Nejati S, Qi G, Giannelis EP, Elimelech M (2014) In situ formation of silver nanoparticles on thin-film composite reverse osmosis membranes for biofouling mitigation. Water Res 62:260-270

Beving D, O'Neill CR, Yan Y (2008) Hydrophilic and antimicrobial lowsilica-zeolite LTA and high-silica-zeolite MFI hybrid coatings on aluminum alloys. Microporous Mesoporous Mater 108:77-85

Bikaï J, Limousy L, Dutournié P, Josien L, Blel W (2015) Stabilisation of the water permeability of mineral ultrafiltration membranes: a numerical approach of surface and pore hydration. C R Chim 18:56-62

Caro J, Noack M (2010) Zeolite membranes-status and prospective. Advances in Nanoporous Materials 1:1-96

Chevereau E, Limousy L, Dutournié P (2011) Use of mordenite surface acidity properties for the selective separation of halide salts: modification of dielectric effects. Ind Eng Chem Res 50:4003-4010

Chevereau E, Zouaoui N, Limousy L, Dutournié P, Déon S, Bourseau P (2010) Surface properties of ceramic ultrafiltration $\mathrm{TiO}_{2}$ membranes: effects of surface equilibriums on salt retention. Desalination 255:1-8

Damm C, Münstedt H, Rösch A (2008) The antimicrobial efficacy of polyamide 6/silver nano- and micro-composites. Mater Chem Phys 108:61-66

Davis JA, Leckie JO (1978) Surface ionization and complexation at the oxide/water interface II. Surface properties of amorphous iron oxyhydroxide and adsorption of metal ions. J Colloid Interface Sci 67(1):90-107

De la Rosa-Gomez I, Olguin MT, Alcantara D (2010) Silver-modified Mexican clinoptilolite-rich tuffs with various particle sizes as antimicrobial agents against Escherichia coli. J Mex Chem Soc 54(3): 139-142

Dong H, Bell T (1999) State-of-the-art overview: ion beam surface modification of polymers towards improving tribological properties. Surf Coat Technol 111:29-40

Dror-Ehre A, Adin A, Markovich G, Mamane H (2010) Control of biofilm formation in water using molecularly capped silver nanoparticles. Water Res 44(8):2601-2609
Faille C, Bénézech T, Blel W, Ronse A, Ronse G, Clarisse M, Slomianny C (2013) Role of mechanical vs. chemical action in the removal of adherent Bacillus spores during CIP procedures. Food Microbiol 33: 149-157

Feng QL, Wu J, Chen GQ, Cui FZ, Kim TN, Kim JO (2000) A mechanistic study of the antibacterial effect of silver ions on Escherichia coli and Staphylococcus aureus. J Biomed Mater Res 52(4):662-668

Friedman BA, Dugan P (1968) Concentration and accumulation of metallic ions by the bacterium Zoogloea. Dev Ind Microbiol 9:381-388

Grass G, Rensing C, Solioz M (2011) Metallic copper as an antimicrobial surface. Appl Environ Microbiol 77:1541-1547

Hincapie BO, Garces LJ, Zang Q, Sacco A, Suib SL (2004) Synthesis of mordenite nanocrystals. Microporous Mesoporous Mater 67:19-26

ISO 22196 (2007) (E), Plastics - measurement of antibacterial activity on plastics surfaces.

Li Q, Mahendra S, Lyon DY, Brunet L, Liga MV, Li D, Alvarez PJJ (2008) Antimicrobial nanomaterials for water disinfection and microbial control: potential applications and implications. Water Res 42:4591-4602

Liau SY, Read DC, Pugh WJ, Furr JR, Russell AD (1997) Interaction of silver nitrate with readily identifiable groups: relationship to the antibacterial action of silver ions. Lett Appl Microbiol 25(4):279-283

Limousy L, Dutournié P, Chevereau-Landais E (2013) Description of the preferential transport of monovalent salts through $\mathrm{Na}$-mordenite membrane: Physico-chemical aspects. Microporous Mesoporous Mater 167:133-136

Makita T, Nakajima K, Ogura T (1999) Antimicrobial zeolite compositions containing alkali metal oxides or alkaline earth oxides for polymers. Brevet, Jpn. Kokai Tokkyo Koho, JP 11246322A 19990914.

Nakao SI (1994) Determination of pore size and pore size distribution 3. Filtration membranes. J Membr Sci 96:131-165

Panácek A, Kvítek L, Prucek R, Kolár M, Vecerová R, Pizúrová N (2006) Silver colloid nanoparticles: synthesis, characterization, and their antibacterial activity. J Phys Chem B 110(33): 16248-16253

Park HJ, Kim JY, Kim J, Lee JH, Hahn JS, MB G, Yoon J (2009) Silverion-mediated reactive oxygen species generation affecting bactericidal activity. Water Res 43(4):1027-1032

Prescott LM, Harley JP, Klein DA (2003) Microbiologie. 2nd Ed [French]. Bruxelles: Boeck, Chap 3:28-59

Qu X, Alvarez PJJ, Li Q (2013) Applications of nanotechnology in water and wastewater treatment. Water Res 47:3931-3946

Sabbani S, Gallego-Perez D, Nagy A, James Waldman W, Hansford D, Dutta PK (2010) Synthesis of silver-zeolite films on micropatterned porous alumina and its application as an antimicrobial substrate. Microporous Mesoporous Mater 135:131-136

Schick J, Daou TJ, Caullet P, Paillaud JL, Patarin J, Mangold-Callarec C (2011) Surfactant-modified MFI nanosheets: a high capacity anionexchanger. Chem Commun 47(3):902-904

Sondi I, Slopek-Sondi B (2004) Silver nanoparticles as antimicrobial agent: a case on E. coli as a model for gram-negative bacteria. $\mathrm{J}$ Colloid Interface Sci 275(1):177-182

Tong G, Yulong M, Peng G, Xirong X (2005) Antibacterial effects of the $\mathrm{Cu}$ (II)-exchanged montmorillonite on Escherichia coli K88 and Slamonella choleraesuis. Vet Microbiol 105: $113-122$

Wicken AJ (1985) Bacterial adhesion. Mechanisms and physiological significance. 2. Bacterial cell walls and surfaces. Plenum Press, New York

Wilhelm FX, Daune M (1969) Interactions of metallic ions with DNA. Biopolymers 8:121-137 
Xu X, Ding H, Wang B (2010) Preparation and performance of $\mathrm{Ag}^{+}-$ $\mathrm{Zn}^{2+}$-zeolite antimicrobial and antibacterial plastic. Adv Mater Res 96:151-154

Yang MR, Chen KS, Tsai JC, Tseng CC, Lin SF (2002) The antibacterial activities of hydrophilic-modified nonwoven PET. Mater Sci Eng 20:167-173
Yoon K-Y, Byeon JH, Park J-H, Hwang J (2007) Susceptibility constants of Escherichia coli and Bacillus subtilis to silver and copper nanoparticles. Sci Total Environ 373:572-575

Zondervan E, Betlem BHL, Roffel B (2007) Development of a dynamic model for cleaning ultrafiltration membranes fouled by surface water. J Membr Sci 289:26-31 